\title{
Ph Unknown/BCR-
}

National Cancer Institute

\section{Source}

National Cancer Institute. Ph Unknown/BCR-. NCl Thesaurus. Code C70627.

Philadelphia chromosome abnormality; $\mathrm{t}(9 ; 22)(\mathrm{q} 34 ; \mathrm{q} 11)$ was not tested; therefore it is not known whether it is present or not; bcr/abl gene rearrangement was not found. 